\title{
Neuroimaging and spectroscopy in children with epileptic encephalopathies
}

United Medical and Dental Schools, Guy's Campus, London, UK A P J Parker

$S$ Keevil

M Newbold

T Cox

M Maisey

R O Robinson

Department of Paediatric Neurology, Leeds General

Infirmary, Leeds, UK

C D Ferrie

Correspondence to: Dr A P J Parker, Newcomen Centre, Guy's Hospital, London SE1 9RT, UK.

Accepted 9 March 1998

\author{
Alasdair P J Parker, Colin D Ferrie, Steven Keevil, Marcus Newbold, Timothy Cox, \\ Michael Maisey, Richard O Robinson
}

\begin{abstract}
Aims-To investigate the nature of the unifocal cortical abnormalities on FDG positron emission tomography (PET) in children with an epileptic encephalopathy but no focal abnormality on electroencephalogram or standard magnetic resonance imaging (MRI).

Methods-Repeat FDG PET, surface rendered high resolution MRI, and single voxel magnetic resonance proton spectroscopy of the areas of abnormal metabolism compared to the contralateral side in 11 children aged 2 to 12 years. Imaging was repeated after a median of 13 months.

Results-Visual analysis of repeat FDG PET revealed similar abnormalities in 10 of 11 children. Semiquantitative analysis revealed similar sited abnormalities in eight children. One child with ictal hypermetabolism initially had an inconsistent second scan. Magnetic resonance spectra in three children showed the $\mathbf{N}$-acetylaspartate/choline ratio was lower in the hypometabolic focus than in the reciprocal area on the opposite side, in two children it was higher, and in one child it was equal. Surface rendered MRI was normal in seven of eight children, and showed temporal lobe asymmetry in one. Conclusion-In children with established epileptic encephalopathies most hypometabolic areas on FDG PET are stable over time. While focal neuronal loss is likely in these areas in some children, microdysplasias or other focal cortical dysplasias are probable in others. (Arch Dis Child 1998;79:39-43)
\end{abstract}

Keywords: epilepsy; Lennox-Gastaut syndrome; magnetic resonance spectroscopy; positron emission tomography

Epileptic encephalopathies are a group of disorders characterised by multiple seizure types and diffusely slow electroencephalogram (EEG) with generalised or multifocal abnormalities. ${ }^{12}$ They are normally described as cryptogenic (previously abnormal) or symptomatic (cause known), and more recently as idiopathic (previously normal). Most patients present in the first years of life and often have severe learning difficulties. ${ }^{1}$ Neuropathological studies have identified some children with epileptic encephalopathies as having microscopic abnormalities such as cortical dysplasias, gliosis, and neuronal heterotopias. ${ }^{134}$ Many of these children have normal computed tomo- graphy (CT) and magnetic resonance imaging (MRI)..$^{5-7}$

Ferrie et al described ${ }^{18}$ fluorodeoxyglucose positron emission tomography (FDG PET) in a group of 32 children with cryptogenic epileptic encephalopathies who lacked focal abnormalities on conventional MRI. ${ }^{8}$ Twelve of these children had unilateral areas of abnormal cortical metabolism. In 11 the scans were considered interictal and showed a hypometabolic defect. One, unintentionally ictal, showed a hypermetabolic defect. The remaining children had either multifocal or diffuse hypometabolism, or normal scans.

In some children with West's syndrome these abnormalities are associated with cortical disease. ${ }^{5}$ The consistency of these focal areas of hypometabolism has been questioned. ${ }^{9}$ This study aimed to establish the consistency over time of the metabolic abnormalities reported by Ferrie $e t a l,{ }^{8}$ and to investigate the nature of these areas using three dimensional, volume rendered reconstruction of the MRI, and acquisition of proton magnetic resonance spectra (MRS).

\section{Materials and methods}

Thirteen children (seven male) with epileptic encephalopathies and unifocal cortical metabolic abnormalities identified on FDG PET were studied prospectively. Three were classed as having typical Lennox-Gastaut syndrome (LGS), in two following infantile spasms and in one arising de novo. Two children were classed as having infantile spasms developing into atypical LGS, two as atypical myoclonic astatic epilepsy, two as typical severe myoclonic epilepsy in infancy, and four could not be classed into a recognised syndrome. International League Against Epilepsy syndromic classification, ${ }^{10}$ video EEG, MRI, FDG PET protocol, and the definition of typical and atypical syndromes have been described previously by Ferrie et al. ${ }^{8}$ In their report unequivocal abnormality was defined as $>15 \%$ asymmetry on semiquantitative analysis of the FDG PET scan. In our study we included one further child with $10 \%$ asymmetry initially.

These children were investigated on a presurgical, clinical protocol, and thus formal ethical approval was not sought. However, informed consent was given verbally for children where sedation was used and in writing for the one case where a general anaesthetic was given for the MRI/MRS. The severity of learning difficulties in the children precluded obtaining informed consent from them.

The following further investigations were performed: 
1. Repeat FDG PET scan at least six months after the initial scan. Visual and semiquantitative analysis were performed using the same protocol as the initial scan.

2. Three dimensional volume rendered reconstruction of MRI images was performed using the ANALYZE ${ }^{11}$ software package from a fast field echo sequence in four children (typical resolution $0.9 \times 0.9 \times 3 \mathrm{~mm}$ ) and a turbospin echo sequence (repetition time $975 \mathrm{~ms}$ and echo time $12 \mathrm{~ms}$, typical resolution $0.9 \times 0.9 \times 1.5 \mathrm{~mm}$ ) in the others. The reconstructions were examined by an experienced neuroradiologist blind to other data. The cortex/cerebrospinal fluid delineation was clearer using the turbospin echo sequence.

3. Proton MRS were acquired from $25 \times 15 \times 15 \mathrm{~mm}$ voxels positioned over the hypometabolic area identified on FDG PET and from the contralateral side. Control values were obtained from the midtemporal lobes in nine adult controls (range 26-54 years, median 32 years) as N-acetylaspartate (NAA), creatine, and choline reach adult values by 100 weeks after birth. ${ }^{12}{ }^{13}$ As it is difficult to equate the size of specific peaks with absolute concentrations of specific molecules, most reports including our own measure the NAA/ choline, or NAA/choline plus creatine when it is not possible to separate the overlapping peaks. ${ }^{12-14}$ The NAA, choline, and creatine spectra were acquired using the point resolved spectroscopy (PRESS) technique (repetition time $1500 \mathrm{~ms}$, echo time $272 \mathrm{~ms}) .{ }^{15}$ Spectra were analysed using the variable projection method (VARPRO), ${ }^{16}$ in which a family of exponential curves are iteratively fitted to the spectroscopic data in the time domain (fig 1). The relative signal intensities due to $\mathrm{N}$-acetyl moieties (NAA), choline containing compounds, and creatine plus phosphocreatine were determined. $T_{1}$ and $T_{2}$ correction was not performed.

Results are given as a ratio between metabolite peak areas with $95 \%$ confidence intervals. Significant difference was defined as values more than 2 standard deviations from the mean of the controls, and asymmetry as mutually exclusive confidence intervals between the left and right ratios.

\section{Results}

The mean age at seizure onset was 12 months (range 1-36) and at the time of initial FDG PET scan was 8 years (range $2-12$ years).

FDG PET imaging was repeated in 11 children with unifocal hypometabolism after a median of 13 months (range 7-18). In 10 children visual inspection revealed cortical abnormalities similar to those on the initial scan. In the remaining child no abnormality was apparent (case 3 in table 1 ).

Of the eight children in whom initial semiquantitative analysis showed an asymmetry of $\geqslant 15 \%$, six had the same asymmetry on repeat investigation in the same cortical region. The asymmetry in the remaining two children was $6 \%$ and $7 \%$ in the same area. Of the three
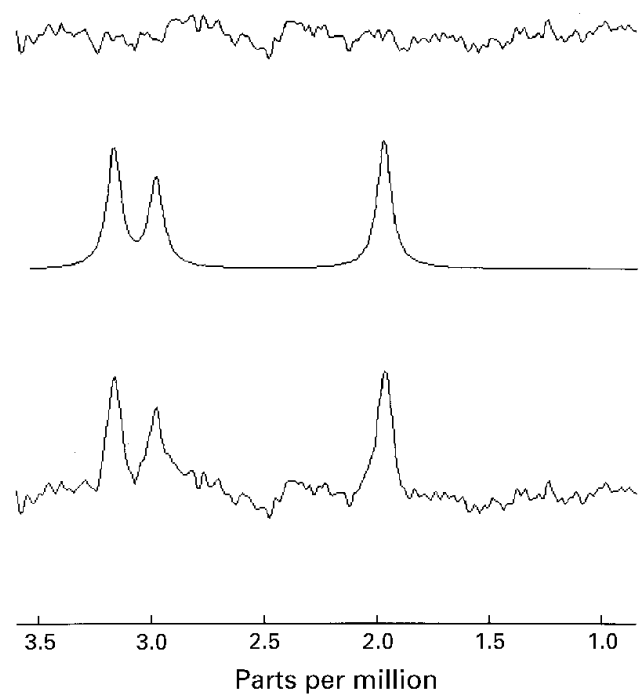

Figure 1 Magnetic resonance spectrum analysed by VARPRO. Lower, Spectrum acquired using PRESS; Middle, Analysis by VARPRO in which a family of exponential curves have been iteratively fitted to the spectroscopic data in the time domain and the baseline subtracted; Upper, Baseline subtracted by VARPRO.

children with $10-15 \%$ asymmetry initially, changes were more localised in one child, abnormality was in the medial rather than lateral temporal lobe in one, and the third child had left temporoparietal hypometabolism on the initial scan, and on repeat had multifocal abnormalities.

The patient with unifocal hypermetabolism initially had unifocal hypermetabolism in the corresponding area on the contralateral side on repeat and was considered to be another ictal scan.

The three dimensional reconstruction of the cerebral surface was successful in all cases using the turbospin echo sequence with slice thickness $<1.6 \mathrm{~mm}$. In one child (case 10) with right anterior temporal lobe hypometabolism of $>15 \%$ on initial and repeat FDG PET scan, the right anterior temporal lobe was smaller than the left. The remaining reconstructions showed neither asymmetry nor other cortical abnormalities.

In the controls, proton MRS showed a mean (2 SD) ratio for NAA/choline, NAA/creatine, NAA/creatine plus choline, and creatine/ choline of 2.01 (0.46), 2.31 (0.60), 1.07 $(0.24)$, and $0.86(0.22)$, respectively. Confidence intervals between left and right values overlapped in all the NAA/choline and creatine/choline ratios, and in eight of nine of the NAA/creatine and NAA/creatine plus choline ratios.

Proton MRS were obtained in six children. In three the NAA/choline ratio was significantly lower in the hypometabolic area than on the contralateral side. Of these children the reduction was unilateral in one and bilateral in two, but was significantly lower in the hypometabolic volume. Significant symmetrical reduction in the NAA/choline ratio was found in one child. In the remaining two the ratio was significantly lower on the side contralateral to the PET abnormality (table 1). The creatine/ choline ratio was lower in the hypometabolic 
Table 1 Investigation results in 12 children with focal hypometabolism on FDG PET scan

\begin{tabular}{|c|c|c|c|c|c|c|c|c|}
\hline \multirow[b]{2}{*}{ Case/sex } & \multirow[b]{2}{*}{ Syndromic classification } & \multirow{2}{*}{$\begin{array}{l}\text { Age at time } \\
\text { of initial } \\
\text { FDG PET } \\
\text { scan }\end{array}$} & \multicolumn{2}{|c|}{ Initial FDG PET result } & \multicolumn{2}{|c|}{ Repeat FDG PET result } & \multirow[b]{2}{*}{$\begin{array}{l}N A A / \text { choline } \\
\text { ratio }(C I)\end{array}$} & \multirow[b]{2}{*}{$\begin{array}{l}3 D \text { surface } \\
M R I\end{array}$} \\
\hline & & & Visual analysis & $\begin{array}{l}\text { Semiquantitative } \\
\text { analysis }\end{array}$ & Visual analysis & $\begin{array}{l}\text { Semiquantitative } \\
\text { analysis }\end{array}$ & & \\
\hline $1 / \mathrm{M}$ & De novo LGS (typical) & $\begin{array}{l}8 \text { years } \\
1 \text { month }\end{array}$ & $\begin{array}{l}\text { Left lateral } \\
\text { temporal } \\
\text { hypometabolism }\end{array}$ & $\begin{array}{l}\text { Left }(12 \%) \\
\text { temporoparietal } \\
\text { hypometabolism }\end{array}$ & $\begin{array}{l}\text { Left lateral } \\
\text { temporal } \\
\text { hypometabolism }\end{array}$ & $\begin{array}{l}\text { Left }(15 \%) \text { lateral } \\
\text { temporal } \\
\text { hypometabolism }\end{array}$ & $\begin{array}{l}\text { L } 1.64(0.21) \\
\text { R } 1.19(0.13)\end{array}$ & - \\
\hline $2 / \mathrm{F}$ & $\begin{array}{l}\text { Infantile spasms } \\
\text { developing LGS } \\
\text { (atypical) }\end{array}$ & $\begin{array}{l}11 \text { years } \\
1 \text { month }\end{array}$ & $\begin{array}{l}\text { Right temporal } \\
\text { hypometabolism }\end{array}$ & $\begin{array}{l}\text { Right }(15 \%) \\
\text { temporal } \\
\text { hypometabolism }\end{array}$ & $\begin{array}{l}\text { Right temporal } \\
\text { hypometabolism }\end{array}$ & $\begin{array}{l}\text { Right }(6 \%) \\
\text { temporal } \\
\text { hypometabolism }\end{array}$ & - & - \\
\hline $3 / \mathrm{F}$ & $\begin{array}{l}\text { Infantile spasms } \\
\text { Developing LGS (typical) }\end{array}$ & 6 months & $\begin{array}{l}\text { Left fronto- } \\
\text { temporoparietal } \\
\text { hypometabolism }\end{array}$ & $\begin{array}{l}\text { Left }(18 \%) \\
\text { fronto- } \\
\text { temporoparietal } \\
\text { hypometabolism }\end{array}$ & Normal & $\begin{array}{l}\text { Left }(7 \%) \text { fronto- } \\
\text { temporoparietal } \\
\text { hypometabolism }\end{array}$ & - & - \\
\hline $4 / \mathrm{M}$ & $\begin{array}{l}\text { Infantile spasms } \\
\text { developing LGS (typical) }\end{array}$ & $\begin{array}{l}10 \text { years } \\
5 \text { months }\end{array}$ & $\begin{array}{l}\text { Left parietal } \\
\text { hypometabolism }\end{array}$ & $\begin{array}{l}\text { Left }(10 / 15 \%) \\
\text { temporoparietal } \\
\text { hypometabolism }\end{array}$ & $\begin{array}{l}\text { Left parietal } \\
\text { hypometabolism }\end{array}$ & $\begin{array}{l}\text { Left }(16 \%) \\
\text { parietal } \\
\text { hypometabolism }\end{array}$ & $\begin{array}{l}\text { L } 1.17(0.07) \\
\text { R } 1.27(0.08)\end{array}$ & - \\
\hline $5 / M$ & $\begin{array}{l}\text { Myoclonic astatic } \\
\text { epilepsy (atypical) }\end{array}$ & $\begin{array}{l}9 \text { years } \\
10 \text { months }\end{array}$ & $\begin{array}{l}\text { Left } \\
\text { temporoparietal } \\
\text { hypometabolism }\end{array}$ & $\begin{array}{l}\text { Left }(10 \%) \\
\text { temporoparietal } \\
\text { hypometabolism }\end{array}$ & $\begin{array}{l}\text { Left } \\
\text { temporoparietal } \\
\text { hypometabolism }\end{array}$ & $\begin{array}{l}\text { Left and right } \\
\text { areas of } \\
\text { hypometabolism }\end{array}$ & $\begin{array}{l}\text { L } 2.13(0.11) \\
\text { R } 1.61(0.12)\end{array}$ & Normal \\
\hline $6 / M$ & $\begin{array}{l}\text { Severe myoclonic epilepsy } \\
\text { of infancy (typical) }\end{array}$ & $\begin{array}{l}10 \text { years } \\
0 \text { months }\end{array}$ & $\begin{array}{l}\text { Right temporal } \\
\text { hypometabolism }\end{array}$ & $\begin{array}{l}\text { Right }(13 \%) \\
\text { medial temporal } \\
\text { hypometabolism }\end{array}$ & $\begin{array}{l}\text { Right temporal } \\
\text { hypometabolism }\end{array}$ & $\begin{array}{l}\text { Right }(7 \%) \\
\text { lateral temporal } \\
\text { hypometabolism }\end{array}$ & - & Normal \\
\hline $7 / \mathrm{M}$ & $\begin{array}{l}\text { Severe myoclonic epilepsy } \\
\text { of childhood (typical) }\end{array}$ & $\begin{array}{l}9 \text { years } \\
9 \text { months }\end{array}$ & $\begin{array}{l}\text { Right temporal } \\
\text { hypometabolism }\end{array}$ & $\begin{array}{l}\text { Right }(>15 \%) \\
\text { temporal } \\
\text { hypometabolism }\end{array}$ & Not repeated & Not repeated & - & Normal \\
\hline $8 / \mathrm{F}$ & $\begin{array}{l}\text { Myoclonic astatic } \\
\text { epilepsy (atypical) }\end{array}$ & $\begin{array}{l}12 \text { years } \\
2 \text { months }\end{array}$ & $\begin{array}{l}\text { Right } \\
\text { temporoparietal } \\
\text { hypometabolism }\end{array}$ & $\begin{array}{l}\text { Right }(20 \%) \\
\text { temporal } \\
\text { hypometabolism }\end{array}$ & $\begin{array}{l}\text { Right } \\
\text { temporoparietal } \\
\text { hypometabolism }\end{array}$ & $\begin{array}{l}\text { Right }(22 \%) \\
\text { temporal } \\
\text { hypometabolism }\end{array}$ & - & Normal \\
\hline $9 / \mathrm{F}$ & Unclassified & $\begin{array}{l}2 \text { years } \\
3 \text { months }\end{array}$ & $\begin{array}{l}\text { Left anterior } \\
\text { temporal } \\
\text { hypometabolism }\end{array}$ & $\begin{array}{l}\text { Left }(15 / 18 \%) \\
\text { anteriomedial } \\
\text { temporal } \\
\text { hypometabolism }\end{array}$ & $\begin{array}{l}\text { Left anterior } \\
\text { temporal } \\
\text { hypometabolism }\end{array}$ & $\begin{array}{l}\text { Left }(39 \%) \\
\text { anterior temporal } \\
\text { hypometabolism }\end{array}$ & $\begin{array}{l}\text { L } 1.02(0.06) \\
\text { R } 1.37(0.14)\end{array}$ & Normal \\
\hline $10 / M$ & Unclassified & $\begin{array}{l}7 \text { years } \\
11 \text { months }\end{array}$ & $\begin{array}{l}\text { Right anterior } \\
\text { temporal } \\
\text { hypometabolism }\end{array}$ & $\begin{array}{l}\text { Right }(35 \%) \\
\text { anteriomedial } \\
\text { temporal } \\
\text { hypometabolism }\end{array}$ & $\begin{array}{l}\text { Right anterior } \\
\text { temporal } \\
\text { hypometabolism }\end{array}$ & $\begin{array}{l}\text { Right }(35 / 15 \%) \\
\text { anteriomedial } \\
\text { temporal } \\
\text { hypometabolism }\end{array}$ & $\begin{array}{l}\text { L } 1.55(0.11) \\
\text { R } 0.93(0.07)\end{array}$ & $\begin{array}{l}\text { Smaller right } \\
\text { temporal } \\
\text { lobe }\end{array}$ \\
\hline $11 / M$ & Unclassified & $\begin{array}{l}3 \text { years } \\
10 \text { months }\end{array}$ & $\begin{array}{l}\text { Right temporal } \\
\text { hypometabolism }\end{array}$ & $\begin{array}{l}\text { Right }(20 \%) \\
\text { temporal } \\
\text { hypometabolism }\end{array}$ & $\begin{array}{l}\text { Right temporal } \\
\text { hypometabolism }\end{array}$ & $\begin{array}{l}\text { Right }(14 \%) \\
\text { temporal } \\
\text { hypometabolism }\end{array}$ & $-\pi$ & - \\
\hline $12 / \mathrm{F}$ & Unclassified & $\begin{array}{l}5 \text { years } \\
0 \text { months }\end{array}$ & $\begin{array}{l}\text { Left temporal } \\
\text { hypometabolism }\end{array}$ & $\begin{array}{l}\text { Left }(19 \%) \\
\text { temporal } \\
\text { hypometabolism }\end{array}$ & $\begin{array}{l}\text { Left temporal } \\
\text { hypometabolism }\end{array}$ & $\begin{array}{l}\text { Left }(27 \%) \\
\text { temporal } \\
\text { hypometabolism }\end{array}$ & $\begin{array}{l}\text { L } 0.77(0.09) \\
\text { R } 1.15(0.11)\end{array}$ & Normal \\
\hline
\end{tabular}

LGS, Lennox-Gastaut syndrome; L, left; R, right.

focus compared to the contralateral side in two children; in four there was no difference.

\section{Discussion}

This study demonstrates that focal PET abnormalities in established childhood epileptic encephalopathies are stable over time. This is at variance with the report of 15 children with West's syndrome by Maeda et al in whom some metabolic abnormalities were transient. ${ }^{9}$ However, in their series the initial scan was performed early in the encephalopathy and the repeat before the children were 12 months old in $75 \%$ of cases. Five children subsequently became seizure free and are a different population from those in our study. Our report and that of Maeda et al when taken together suggest that metabolic abnormalities on FDG PET are evident early in the encephalopathy in children with early remission of seizures they may resolve. Despite similar initial clinical manifestations the causes of the encephalopathies in these children are likely to differ from those in whom the seizures continue and who have stable metabolic abnormalities.

Snead et al reported concordance of FDG PET abnormality and seizure focus on subdural mapping in only two of 13 children with "medically intractable epilepsy" undergoing resective surgery. ${ }^{17}$ They also reported good outcome after resection of abnormal areas identified on EEG and MRI in patients with normal FDG PET scans and abnormalities on subdural mapping that were more widespread than those evident on FDG PET. ${ }^{17}$ This is at variance with the report by Chugani et al of 23 children with infantile spasms where the position of the FDG PET abnormality was the same as that on the EEG, and after removal of this area 15 were seizure free after a mean follow up of 28 months. ${ }^{5}$

Three dimensional MRI was normal in all but one child in our series, suggesting that pathological abnormalities underlying the metabolic ones are unlikely to be macroscopic. Sisodaya et al reported a series of adults with intractable complex partial seizures and normal standard MRI; $47 \%$ had subtle abnormalities of gyri/sulci such as stellate formations and a submerged central gyrus. ${ }^{18}$ Our group of children did not have such abnormalities. The temporal lobe rendering was of particular importance as most of the hypometabolic areas were temporal, but this was technically the most difficult area to render because of the close proximity of bone and blood vessel.

Proton MRS identifying NAA, choline, and creatine peaks has been used to identify neuronal loss in children with temporal lobe epilepsy and hippocampal sclerosis. ${ }^{12}$ As NAA is mainly neuronal, it is found in lower concentrations in areas of neuronal loss. In contrast, choline and creatine are present in most brain cells, particularly glia. ${ }^{1516}$ Hippocampal sclerosis is 
probably an acquired lesion. Our children with epileptic encephalopathies are more likely to have congenital than acquired lesions. The lack of a consistent reduction in the NAA/choline ratio implies that not all the hypometabolic areas seen on FDG PET have significant neuronal loss or that neurons and glia are equally reduced in concentration in a symmetrical manner. This is unlikely in the absence of focal abnormality on MRI. Of note the creatine/ choline ratio was also reduced in two of the hypometabolic areas. Until histology on these volumes is available we are unable to determine whether this is a rise in the choline with a concomitant drop in the NAA - that is, gliosis in addition to neuronal loss. The bilateral reduction in $\mathrm{NAA} /$ choline in three children is consistent with similar reports of both adults and children with intractable partial seizures. ${ }^{12}$

The neuropathology of cortical dysplasias in infantile spasms and other epileptic encephalopathies before the advent of FDG PET has been reported. Cortical malformations can be separated into those with and those without neuronal cytomegaly or hamartomatous malformation of astrocyte-like balloon cells. ${ }^{19}$ Cortical dysplasias can be classified as mild, moderate or severe depending on histological appearances. ${ }^{20}$ They are often unapparent on MRI and may be discrete, multifocal or generalised. ${ }^{518}$ Chugani et al reported a high incidence of cortical dysplasia, gliosis, and neuronal heterotopias; in only one case was the histology normal. ${ }^{5}$ Our group differed from the Chugani et al series where focal features were present on the EEG in all children and $\mathrm{MRI} / \mathrm{CT}$ was abnormal in some.

The high incidence of focal hypometabolism in our series in children with infantile spasms developing into LGS suggests similar pathological processes to these reports ${ }^{519} 20$ adding weight to the argument for separate syndromic classification from de novo LGS. Focal pathological abnormalities are well recognised in de novo LGS, however, nosological difficulties make review of previous literature difficult. Roger et al reported 30 cases presenting from 1963-83. ${ }^{21}$ Several cases had been reclassified as LGS from myoclonic-astatic petit mal. Microdysgenesis, pachygyria, neuronal necrosis, and hypoxic lesions in the neocortex were found in many of the cases. Theodore et al described a series of children with LGS of whom $70 \%$ presented after age 2 years. Most had 2-2.5 slow spike wave discharges, implying more rigorous criteria. ${ }^{22}$ None of their cases had consistent areas of unifocal hypometabolism, in agreement with the cases classified as typical de novo LGS by Ferrie et al. ${ }^{8}$ Chugani et al report multifocal hypometabolism in $70 \%$ of children in a series with LGS. ${ }^{23}$ Only two cases had unifocal hypometabolism and, in these, seizure onset was at three and eight months - an earlier seizure onset than in typical de novo LGS.

Severe myoclonic epilepsy of infancy represents $5 \%$ of epilepsies presenting in the first year of life. ${ }^{24}$ The aetiology of most cases is unknown. ${ }^{24-26}$ Renier and Renkawek report one case with cerebellar microdysgenesis. ${ }^{27}$ In our group, most children with severe myoclonic epilepsy in infancy had normal or multifocal abnormalities on FDG PET scan. There are no reports of pathology in children with myoclonic astatic epilepsy; however, $50 \%$ of these children as well as the unclassifiable group had unifocal FDG PET abnormalities.

In summary, unifocal areas of hypometabolism in children with established epileptic encephalopathies are consistent over time. It is likely that the stability has histopathological correlation. No child with typical de novo LGS had this sign, suggesting differing pathological processes for different syndromes. The hypometabolism was not associated with abnormality on three dimensional surface rendering suggesting microscopic pathology. NAA/ choline ratio was reduced in some but not all children, implying significant neuronal loss is unlikely to be the sole explanation of the metabolic abnormality. The question of whether these children are suitable for resective epilepsy surgery remains unanswered, as outcome following surgery has not been reported on children with established epileptic encephalopathies with focal abnormality on PET only.

ANALYZE was made available through a research agreement with the Biomedical Imaging Resource, Mayo Foundation. The MRS processing software was developed and supported by $\mathrm{Dr} \mathrm{P}$ van Bogaert with funding from the European Commission.

1 Donat JF. The age-dependent epileptic encephalopathies. $\mathcal{F}$ Child Neurol 1992;7:7-21

2 Aicardi J. Epileptic encephalopathies of early childhood. Current Opin Neurol Neurosurg 1992;5:344-8.

3 Riikonen R, Donner M. Incidence and aetiology of infantile spasms from 1960 to 1976: a population study in Finland. Develop Med Child Neurol 1979;21:333-43.

4 Jellinger K. Neuropathological aspects of infantile spasms. Brain Dev 1987;9:349-57.

5 Chugani HT, Shewmon DA, Shields WD, et al. Surgery for intractable infantile spasms: neuroimaging perspectives. Epilepsia 1993;34:764-71.

6 Riikonen R. A long term follow-up study of 214 children with the syndrome of infantile spasms. Neuropediatrics with the syndron

7 van Bogaert P, Chiron C, Adamsbaum C. Value of magnetic resonance imaging in West's syndrome of unknown aetiology. Epilepsia 1993;34:701-6.

8 Ferrie CD, Maisey M, Cox T, et al. Focal abnormalities detected by ${ }^{18} \mathrm{FDG}$ PET in epileptic encephalopathies. Arch Dis Child 1996;75:102-7.

9 Maeda N, Watanabe K, Negoro T, et al. Evolutional changes of cortical hypometabolism in West's syndrome [erratum appears in Lancet 1994;344:415]. Lancet 1994;343:1620-3.

10 Commission On Classification And Terminology of the International League Against Epilepsy. Proposal for revised classification of epilepsies and epileptic syndromes. Epilepsia 1989;30:389-99.

11 Robb RO, Hanson DP, Karwoski RA, Larson AG, Workman EL, Stacey MC. ANALYZE: a comprehensive, operator interactive software package for multidimensional medical 1989;13:433-54.

12 Cross JH, Connelly A, Jackson GD, Johnson CL, Neville BG, Gadian DG. Proton magnetic resonance spectroscopy in children with temporal lobe epilepsy. Ann Neurology in children with

13 Kreis R, Ernst T, Ross BD. Development of the human brain: in vivo quantification of metabolite and water content with proton magnetic resonance spectroscopy. Mag Reson Med 1993;30:424-37.

4 Urenjak J, Williams SR, Gadian DG, Noble M. Proton nuclear magnetic resonance spectroscopy unambiguously identifies different neural cell types. $\mathcal{F}$ Neurosci 1993;13: 981-9.

15 Bottomley PA. Spatial localisation in NMR spectroscopy in vivo. Ann NY Acad Sci 1996;508:333-48.

16 de Beer R, van Ormondt D, Pijnappel WWF, van der Veen JWC. Quantitative analysis of magnetic resonance signals in the time domain. Israel fournal of Chemistry 1988;28: 249-61.

17 Snead OC, Chen LS, Mitchell WG, et al. Usefulness of $[18 \mathrm{~F}]$ fluorodeoxyglucose positron emission tomography in paediatric epilepsy surgery. Pediatr Neurol 1996;14:98-107.

18 Sisodaya SM, Free SL, Fish DR, Shorvon SD. Increasing the yield from volumetric MRI in patients with epilepsy. Magn Reson Imaging 1995;13:1147-52. 
19 Vinters HV, Fisher RS, Cornford ME, et al. Morphological substrates of infantile spasms: studies based on surgically
resected tissue. Childs Nervous System 1992;8:8-17.

20 Mischel PS, Nguyen LP, Vinters HV. Cerebral cortical dysplasia associated with pediatric epilepsy. Review of neuropathologic features and proposal for a grading system. F Neuropathol Exp Neurol 1995;54:137-53.

21 Roger J, Gambarelli-Dubois D. Neuropathological studies of the Lennox Gastaut syndrome. In: Niedermeyer E, Degen R, eds. The Lennox Gastaut syndrome. New York: Alan R Liss, 1987:73-92.

22 Theodore WH, Rose D, Patronas D, et al. Cerebral glucose metabolism in the Lennox Gastaut syndrome. Ann Neurol 1987;21:14-21.

23 Chugani HT, Mazziotta JC, Engel J Jr, Phelps ME. The Lennox-Gastaut syndrome: metabolic subtypes determined by 2-deoxy-2 [18F]fluoro-D-glucose positron emission tomography. Ann Neurol 1987;21:4-13.

24 Dravet C, Bureau M, Guerrini R, Giraud N, Roger J. Severe myoclonic epilepsy in infancy. In: Roger J, Bureau M, Dravet C, Dreifuss FE, Perret A, Wolf P, eds. Epileptic syndromes in infancy, childhood and adolescence. London: John Libbey, 1992:75-88.

25 Yakoub M, Dulac O, Jambaque I, Chiron C, Plouin P. Early diagnosis of severe myoclonic epilepsy in infancy. Brain Dev 1992;14:299-303.

26 Fejerman N. Severe myoclonic epilepsy of infancy. In: Wallace S, ed. Epilepsy in children. London: Chapman and Hall, 1995:241-6.

27 Renier WO, Renkawek K. Clinical and neuropathologic findings in a case of severe myoclonic epilepsy of infancy. Epilepsia 1990;31:287-91.

When is child sexual abuse not child sexual abuse?

Some definitions of sexual abuse include a requirement that it should violate societal taboos. In some societies sex between an adult man and a girl is not unusual and not taboo. In an article in Genitourinary Medicine (E Klouman and colleagues. Genitourinary Medicine 1997;73:5227) the authors write that, in a traditional African society, adult men's sex with underage girls "cannot by definition be described as sexual abuse of children in the Western sense".

These authors list 16 studies published between 1986 and 1996 about child sexual abuse and the occurrence of sexually transmitted infections in children in Africa. They themselves studied 552 children under 15 and their household members in a rural village in Tanzania. They found a positive Treponema pallidum haemagglutination test in $6.4 \%$ of girls and $1.1 \%$ of boys. In older children (10-14) the seroprevalences were $11 \%$ and $1 \%$. The test results in adult family members did not suggest transmission from fathers to daughters and the marked sex difference is taken as evidence against a non-venereal treponemal disease such as yaws. They believe that these girls have syphilis and contracted it from adults outside their own households.

Child sexual abuse is something that harms children. That which does harm to a child and can be avoided is child abuse. Unless or until there is evidence that adult sex with children within a society that tolerates it does not harm the child then such practice is sexual abuse in "the Western" or any other reasonable sense. (Child sexual abuse has not always been condemned in our own society. In one of the most praised novels of the century (Gabriel Garcia Márquez. Love in the time of cholera. London: Penguin, 1989) the main character ("hero?") has regular sex with a 14 year old placed in his care, without too much in the way of apparent censure, and ends up getting the woman he always wanted and living happily ever after. 